\title{
EXPLAINING SPATIAL VARIATION IN HOUSING CONSTRUCTION ACTIVITY IN TURKEY
}

\author{
Elif ALKAY ${ }^{1}$, Craig WATKINS ${ }^{2 *}$, Berna KESKIN² \\ ${ }^{1}$ Department of Urban and Regional Planning, Istanbul Technical University, Istanbul 34437, Turkey \\ ${ }^{2}$ Department of Urban Studies and Planning, University of Sheffield, Western Bank, Sheffield S10 2TN, UK
}

Received 22 March 2016; accepted 8 March 2017

\begin{abstract}
In Turkey, there has been a strong policy narrative that has emphasized the importance of construction activity as a driver of economic growth. This has given shape to a central state-led policy regime that has sought to ensure that planners and other urban policy makers develop plans and strategies that support construction activity. Against this backdrop, and a recent history of uneven spatial development, this paper seeks to understand what this policy imperative might mean for housing construction activity in different provinces. It seeks to reflect on both the relationship between the state and the market, and the interaction between state policies, economic drivers and levels of construction activity. The evidence presented in the paper suggests that uneven spatial development might be explained in different ways in different provinces. Although, in many cases, patterns of construction activity are consistent with economic fundamentals, there are important exceptions in some regions where arguably activity levels are at odds with prior expectations.
\end{abstract}

Keywords: housing construction, spatial analysis, Turkey, economic growth, planning policy.

\section{Introduction and motivation for the study}

Although there is a long-standing interest in understanding the cyclical forces that drive economic growth and urban development, much of the empirical analysis has tended to focus on the United Kingdom and North America (see Buckley, 1952 for an example; and Barras, 2009 for a review). The analysis also tends to focus on either national trends (Tsolacos, McGough, \& Keogh, 1998) or city case studies (Barras, 1984; Fainstein, 2001). This paper is intended to both build on and extend the insights from this literature. It does so, first, by exploring the relationship between economic growth and construction in an emerging (as opposed to mature) real estate market context, and second, by examining intra-regional differences within the study area which, in this case, is Turkey.

As in many emerging markets, there has been an intense focus on the workings of the real estate sector and on the levels of construction sector activity in Turkey. This is a result of the primacy given to development activity as a driver of economic growth by central government. The real estate market is viewed as a means of attracting globally circulating capital, of stimulating the influx of foreign investment and of inducing construction activities, all of which have been viewed as effective strategies for accelerating economic growth since 2000 (Eraydin \& Tasan-Kok, 2014). Since the financial crisis in 2001, the decrease in interest rates, low inflation rates and the strong growth rates in the economy have stimulated investment in the property market. In addition to the significant economic recovery process, the reforms on construction sector have driven the increased demand and supply in the user, investor and developer submarkets of the real estate sector (Coskun, 2011).

This has partly been assisted by a pro-construction policy regime, where the State's Urban Transformation programme, change to planning law and enhancements to the powers of institutions such as TOKI, the national state development agency, have helped underpin large-scale housing projects; regional infrastructure projects; leading to shopping malls and skyscrapers being developed throughout Turkey and especially in the major cities (see Turk \& Korthals Altes, 2010; Turkun, 2011; Celik, 2013 for more details). Most of these projects were carried out via public and private partnerships where public authorities provided land on the principle of a yield sharing model.

${ }^{*}$ Corresponding author. E-mail: c.a.watkins@sheffield.ac.uk 
Thus, instead of relying solely on market dynamics, the state took an active role in market stimulus by changing the legislation to facilitate reconstruction in brownfield areas (Eraydin \& Tasan-Kok, 2014; Celik, 2013) and by directly proving land for these large scale projects. In the last decade, the economic growth in Turkey has been underpinned to a large degree by these government led reforms with urban property markets used as a key vehicle for growth (Eraydin \& Tasan-Kok, 2014).

Against this backdrop, this paper posits that there is a need to understand the different factors that shape the relationship between economic growth and housing construction levels. We contend that such a discussion: can help understand and better inform the role of central and local policies intended to foster housing construction growth, and to provide flexible business environment for housing investments; can help determine the potentials (or limitations) of different areas that have attracted (or failed to attract) construction investment; can enhance our understanding of the role of planning at local and national level and its contribution in particular in encouraging housing investments; can help us reflect on the strengths and weaknesses of current spatial variations in attempts to develop sustainable development strategies. At the heart of this analysis is the concern that uneven development of housing construction might be driven by speculative housing bubbles in individual cities, where real estate values and market activity have become divorced from economic fundamentals. Our analysis is tended to inform policy development in emerging markets. In this context the overall aim of this paper is to explore the relationship between policy interventions and initiatives, housing construction activity, and economic growth in Turkey between 2002/3 and 2013.

The paper has four further sections. Section 1 provides a review of the literature that explores the relationship between public policy, markets and development activity. This review offers a clear indication of the myriad influences that shape development activity in different contexts. Section 2 sets out the design of our empirical research. Section 3 provides an overview of the study area and outlines the trends in key economic and construction sector indicator. It also sets out the initial findings based on our spatial statistical analysis. Section "Conclusions" offers some preliminary conclusions and sets out an agenda for further research.

\section{Literature review}

There has been long-standing interest in the relationship between construction activity in the wider economy. One strand of the literature has focused on the economic impacts of construction (see Turin, 1969; Strassmann, 1970), while the other has looked at the way in which the economy has shaped the pattern and volume of construction activity (Barras, 2009).

In the former context, Bon (1992) takes a very longterm view of construction activity in different countries and argues that construction's contribution to economic growth varies at different points in the business cycle. He explains that, in general, construction's contribution to economic output takes a bell shaped pattern, rising initially but falling again over time. He also notes that construction activity has a global dimension with activity spilling over from advanced economies with high levels of physical capital to emergent and developing market contexts. More recently, Ruddock and Lopes (2006) revisited the idea of the Bon curve and, although using data spanning different time periods, provide empirical challenge to the notion that the decline in contribution to the economy is inevitable. Sun, Mitra, and Simone (2013) build on this analysis, and using error correction modelling show that the pro-cyclical outcomes are also influenced by demographics and geography.

Even within the increasingly voluminous international literature that explores the real estate construction cycles, the literature is divided into two significant strands: one that deals with non-residential development activity and another that deals with housing sector activity. Both of these strands of the literature provide a useful basis from which to identify the key interactions between public policy and the market and the key drivers of constriction activity.

Studies of the non-residential development cycle tend to be dominated by time-series econometric analyses (Nanthakumaran, Watkins, \& Orr, 2000; Tsolacos et al., 1998). Increasingly, these studies have explored the market supply side (that is development activity) as part of analytical framework that recognises that the commercial real estate sector can usefully to be conceptualised as comprising a set of inter-linked submarkets where both user rights to space (referred to inter alia as the user, occupier or space market) or where investor rights (referred to as the asset, capital or investor market) are traded (see DiPasquale \& Wheaton, 1996; Keogh, 1994; Fisher, 1992). These models demonstrate that development or construction activity is influenced by three key drivers: the business cycle (Key, Zarkesh, MacGregor, \& Nanthakumaran, 1994), investment motives (including the 'magical' properties of real estate, see Keogh, 1994), and development motives that, at times, include autonomous speculative components and herd behaviour (Grenadier, 1995; Barras, 2009). One of the main limitations of these models is that they tend to pay little attention to the role of public policy in shaping real estate actor behaviour in ways that can restrict or enhance the development response (Jackson \& Watkins, 2005, 2007).

Henneberry, McGough, Rowley, and Smith (2003), Henneberry, McGough, and Mouzakis (2005a, 2005b) adapt the standard analytical framework to accommodate policy impacts and explore the extent to which policy interventions might alter market outcomes. In their multiequation model of UK real estate market, they allow the planning regime to influence development activity by factoring using the proportion of planning permissions granted as a proxy measure for policy stance. 
The housing supply literature is slightly different in orientation. While this literature is also dominated by econometric analyses, housing studies tend to pay less attention to investment considerations (other than implicitly) and instead is more likely to pay attention to the role of the state and the impact of policy interventions on market outcomes (see Dawkins \& Nelson, 2002; White \& Allmendinger, 2003; Bramley, 2003, 2013 for reviews of the international literature). Thus, typically, the supply of housing is driven by land values, previous and expected future real estate prices, the cost of borrowing, construction costs, and the planning policy regime. The literature shows that the impact of the policy regime varies considerably between countries, within countries and over time. The methods used to measure policy interventions vary from simple measures based on the proportion of planning applications granted to composite variables based on the survey responses of policy makers (Bramley \& Watkins, 1995; Bramley, 1998).

The weakness in all of these studies is that the measurement of the planning regime and/or policy stance tends to be imperfect. Adams and Watkins (2014) argue that these models tend to under-elaborate the multi-dimensional and complex nature of policy interventions and of state influence on markets. There are three important problems: (i) they under-state the importance of policy in creating a setting for investment and thus fail to allow for the impact on the demand-side of the market (Begg, 2002; Jackson, 2006; Jackson \& Watkins, 2011); (ii) they tend to overlook the complex and often conflicting inter-play between different policy initiatives (Wong \& Watkins, 2009); and (iii) they fail to take account of the importance of institutional design in mediating and mitigating the intended impacts of policy interventions (Adams \& Tiesdell, 2010). Adams and Watkins (2014) go on to argue that a more pluralist research approach is required if we are to fully understand the relationship between the state (policy instruments and strategies) and market outcomes, including the level of development activity.

The next section of this paper begins to apply some of the ideas from this body of literature. We start by using regression analysis to understand the causal relationship between economic fundamentals and construction activity. In the absence, however, of quantitate measures of policy stance or regime, we use the residuals to begin to identify where activity deviates from normal patterns that might be expected under given economic circumstances. We argue that the typology constructed here provides a basis from which to develop a more qualitative investigation of the role and influence of policy interventions on construction activity in different regional economies.

\section{Research design, data and methods}

\subsection{Data}

The data used in this paper is derived from two main sources. The first dataset is drawn from the Turkish Statistical Institute (TUIK) and is collated at NUTS-3 province level; it includes construction permit rates during the
2002-2013 period. Construction permit rates are classified according to building types such as housing, hotels, office buildings, buildings served retail and wholesale, industrial buildings and depots. Since it does not include the other segments of the construction sector such as dams, highways, railways, airports etc., the data set reflect the volume of constructed buildings rather than activity in the whole sector, including infrastructure projects. Thus, when we discuss construction activity, the focus as in the literature review is on housing and non-residential building activity.

The second data source is a set of socio-economic indices generated by a research initiative known as "The socio-economic development levels of provinces" developed by the Ministry of Development. This initiative research was developed initially by the State Planning Organization in 2003 with data collection was repeated in 2013 by the Ministry of Development. Although this second wave developed more indicators than the first one, they both used the same methods and statistical methods to construct the indicators used here. The 2003 project developed 58 indicators that were classified under 2 subheadings: social indicators (demography, employment, education, health, infrastructure and other welfare indicators) and economic indicators (manufacturing sector, construction, agriculture and fiscal indicators). In 2013 this was extended to 61 indicators that were classified under 8 subheadings: demography, employment, education, health, fiscal indicators, quality of life indicators, competitive and innovative capacity indicators, and, accessibility. The index construction methods in both periods used a principal component analysis where the principal component that had the highest variance explanation rate was assigned the main causative factor. The index values calculated based on the main causative factor allowed provinces to be ranked by index values.

\subsection{Analytical methods}

The exploratory spatial and statistical analyses reported here have been developed in two steps. First, the relationship between construction growth and socio-economic development level was explored using OLS regression at the aggregate level. The second step focuses on the spatially uneven levels of construction growth evident in the aggregate data. This is analysed using Moran-I statistics to test for spatial autocorrelation in the regression residuals. Local Moran-I analysis was undertaken to detect whether the provinces are clustered relative to their socio-economic development and construction growth levels.

In the first step, the OLS equations are designed to help discern how much of the construction sector and housing construction (dependent variables) growth, as measured in terms of permits for buildings, can be explained by socio-economic development levels (independent variables). Four different equations were estimated. The first 2 equations used 2003 data and regress socio-economic variables against the two different dependent variables: the total construction growth and housing construction 
respectively. The second 2 equations were used 2013 data. The equations took the standard form:

$$
Y_{C_{t_{1-2}} ; R_{t_{1-2}}}=\alpha+\beta X_{t_{1-2}}+\varepsilon
$$

where: $Y$ is the construction permit rate in $2003\left(t_{1}\right)$ and $2013\left(t_{2}\right)$ and for the all types of constructed buildings $\left(C_{t_{1-2}}\right)$ and permits to residential units $\left(R_{t_{1-2}}\right)$ in those years; $X$ is the socio-economic development level index values in $2003\left({ }_{t_{1}}\right)$ and $2013\left({ }_{t_{2}}\right) ; \beta$ is the estimated parameter that shows the relationship between construction growth and socio-economic development level. The positive value $\beta$ shows the economic development level has positively affect the construction growth. Conversely, a negative value $\beta$ shows the economic development level has reduced the rate of construction growth.

While these equations model the relationship, the residual part $(\varepsilon)$ of the equations illustrates that much of the activity cannot be explained by social and economic change. Spatial analysis of the residuals can, however, provide some insight into what might be missing from the models and can point to where unmeasured factors, such as state intervention, might be having an impact on construction activity levels. Positive values in the residuals suggest that the other factors are likely to offer a better explanation for the growth in construction volumes than the socio-economic development factors included in the model. As we note above, theory tells us that those major factors might include central or local government's policies and public investments, and will encompass the role of spatial planning, the effect of land use regulations, zoning regulations and restrictions, the capacity of land supply for alternative uses, building construction permit ratios and other policy initiatives. Since the both data sets are in NUTS3 level, it is possible to begin to unpack the role of planning and state intervention on the growth of the construction sector on activity in individual cities. This provide an opportunity for comparison and further discussion.

The motivation for our spatial analysis is thus based on the proposition that construction sector investments, and housing construction in particular, should, based on prior economic theory, reflect growth patterns at the aggregate level. Indicators of spatial association are statistics that evaluates the existence of clusters in the spatial arrangement of given variables. Local clusters are groups that have higher or lower rates than might be expected and display statistically significant variations that cannot be explained by chance alone. That is to say, the values occurring are above or below those that would be associated with a random distribution in space. In practice, this means that a straightforward Local Moran-I statistic can be applied to measure the overall clustering of the data. It assumes homogeneity and thus, the null hypothesis $\mathrm{H}_{0}$ is that there is no autocorrelation. If there is no autocorrelation, the fact that two points are close to or distant from each other has no bearing on the relationship between the values at those locations. Conversely, if there is a positive spatial autocorrelation, proximity in space should indicate that there are similarities in attribute values. This allows us to look for patterns (or relationships) within the two key groups identified in our OLS analysis: those where socio-economic factors explain much of the activity; and those where socio-economic factors explain relatively little of what has been happening in the sector.

The Local Moran-I analysis was applied using the spatial analysis program GeoDa. The Local Moran-I approach evaluates clusters in individual units by calculating local Moran-I values for each spatial unit. It allows us to detect local spatial clusters, where the local indicators are causally large or small. While positive I values indicate that the feature is surrounded by features with similar values, negative I values indicate that the feature is surrounded by features with dissimilar values. Spatial clusters shown on the Local Moran-I map only refer to the core of the cluster. We identify an area as being part of a cluster when the value at a location (either high or low) is more similar to its neighbors than would be the case under spatial randomness.

Local Moran-I's graph is visualized as the slope in the scatter plot with the spatially lagged variable (a sum of spatial weights multiplied with values for observations at neighboring locations) on the vertical axis and the original variable on the horizontal axis. Figure 1 summarises the characteristics of each quadrant. In short, each quadrant is defined based on the Local Moran-I analysis of the residuals and assigns provinces to groups based on the extent to which construction activity can be explained by social and economic indicators. The graph shows four different quadrants that are each different in their clustering characteristics. The HH (High, High) and LL (Low, Low) quadrants show the positive autocorrelations, while both the HL and LH quadrants show negative autocorrelations and outliers.

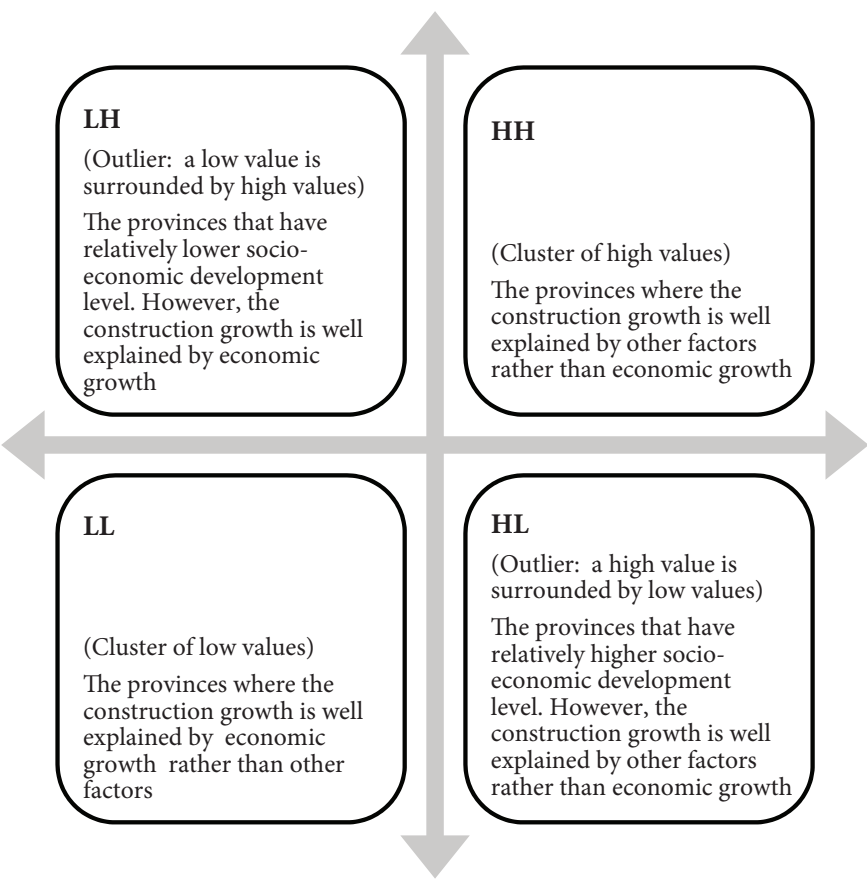

Figure 1. Contextual interpretation of the Local Moran-I graph 
The quadrants allow us to explore the within group similarities and between group dissimilarities in the rate of construction activity and its associated drivers. The differences hint at the factors that might be causing a disjuncture between construction activity and the aspects of construction growth underpinned by social and economic factors. For instance, we hypothesise that provinces in $\mathrm{HH}$ quadrant can be interpreted as localities that stimulate demand creating factors, while the provinces in LL quadrant might be interpreted as provinces that stimulate supply. In this context, demand creating factors include direct public investments, and government incentives as well as the role of planning stimulus (Adams \& Watkins, 2014). Supply creating include the internal, inherent characteristics of the provinces such as the physical suitability of land for development; the extent and nature of existing development; the level of planning controls and planning constraints; and flexibilities in local land supply and planning permissions. Other relevant issues, of course, include the influence of redevelopment costs, land values in existing uses and land costs.

The HL and LH quadrants are outliers in terms of the relationship between economic fundamentals and construction activity. The provinces in the HL quadrant have a mismatch between socio-economic performance and economic development levels. In these cases, it might be that public investments or flexibility in planning regulations or land supply corresponding mixed-used developments are more significant in determining the level of activity. The LH provinces exhibit the polar opposite outcomes from those in the LH quadrant. The question in those localities is what factors have move forward construction beyond the socio-economic development level.

In summary, the questions raised about the relationship between construction activity and economic performance in each quadrant help set the research agenda. It is clear that we need to know more about the nature of the market and influence of local policy intervention and stances.

\section{Empirical analysis of the relationship between the state, the market and development activity}

\subsection{National economic trends and activity}

This section of the paper provides an overview of the drivers of the construction sector and real estate market in Turkey. Although partly pre-dating our study period and not shown on the chart below, the share of GDP from construction sector activity has been $6 \%$ on average between 1998 and 2014 (see Figure 2). The lowest share between 1998 and 2014 was $4 \%$ in the second quarter of the 2001, while the highest share was $6.7 \%$ in the last quarter of 2006 (Turkish Statistical Institute, 2015a). Although the share of GDP seems to have fluctuated significantly prior to 2010, it has clearly been more stable in recent years. The share decreased markedly first in 2001 because of the Turkish economic crisis, and then again in the third quarter of the 2009 as a result of the 2008 world economic crisis.

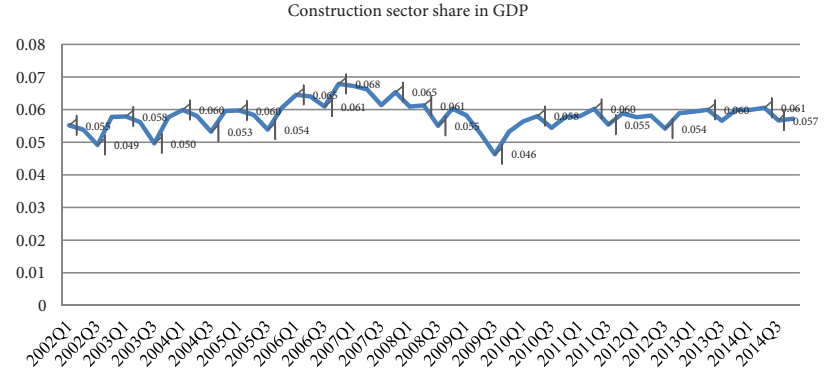

Figure 2. Construction sector share of GDP

While these increases in construction activity appear to have been driven, in large part, by fluctuations in economic growth, it is important, given the two-way relationship between construction activity and economic activity, to identify the nature and direction of the causal relationship between the two.

\section{Economic growth}

Figure 3 shows the growth rates of Turkey's economy in the 2003-2014 periods. The red line shows the rate of change in GDP at constant prices. The blue line shows the growth rates occurred in the construction sector share in GDP. In 2003 as Turkey's economy grew by $5.2 \%$ in real terms from the previous year, the share of the construction sector in the GDP grew by just $2.5 \%$. When the economy contracted by $4.8 \%$ in real terms in 2009 ; the fall in the share of GDP from the construction sector was dramatic at $11 \%$. The correlation coefficient between these two series is 0.84 over the period. Thus, as might be expected, the real growth and the change in the rate of the construction sector in GDP have a direct and strong relationship but it is clearly not a perfect relationship (Turkish Statistical Institute, 2015a).

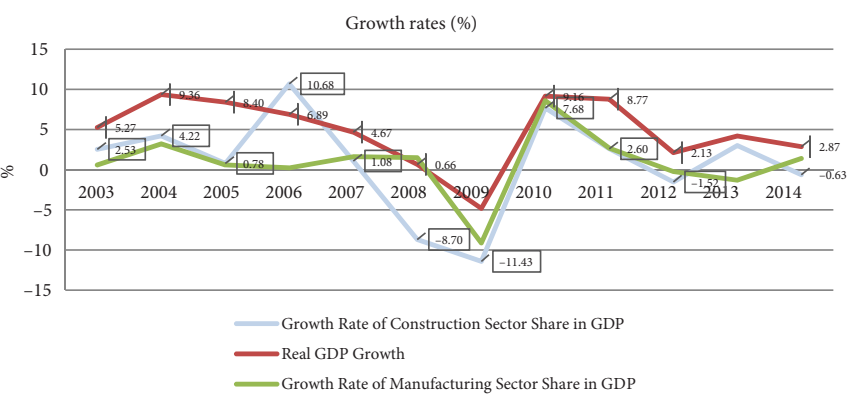

Figure 3. Economic growth rates

\section{Employment trends}

National employment figures between 2005 and 2015 illustrate the importance of the construction sector (see Figure 4). Total employment in the construction sector reached $7.3 \%$ in 2014 compared with 5.6\% in 2005. The highest share of the construction employment in total employment was $7.3 \%$ in the last quarter of the 2013 (Turkish Statistical Institute, 2015b). This share was still at 


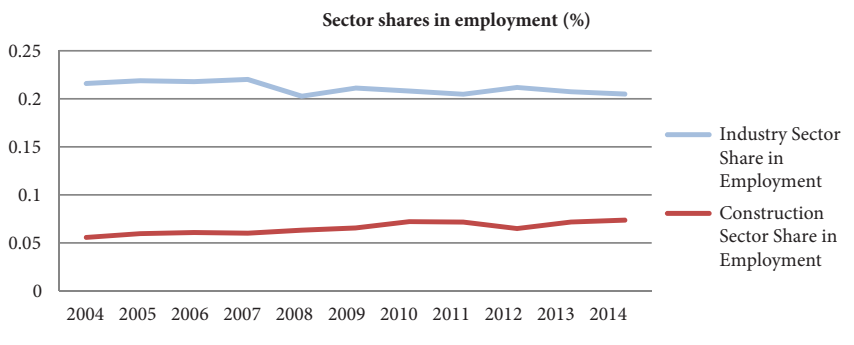

Figure 4. Sector shares in employment

$6.7 \%$ in the first quarter of the 2015. Given that the share of GDP from the construction sector is around 6\%, it might be argued that the construction sector's role in job creation is greater than its weight in terms of output growth.

\section{House price appreciation and investment motives}

Residential development activity has also, as is the case globally, been driven by investment motives as well as economic cycles (Coskun, 2011). In each of the last five years (2010-2014), house prices in Turkey have increased by $63 \%$ on average. Within Istanbul, the rate of appreciation has been $115 \%$ with increase in some parts of the Istanbul market at 175\% (Turkish Central Bank, 2015a).

It is instructive to look at these trends relative to those of other financial assets including gold prices, exchange rates (which govern the value of currency market investments) and the Istanbul Stock Exchange index in last five years. Central Bank data shows that the price per gram of gold bullion has increased $68 \%$ in the last five years; while the price of the US dollar against TL has valued 84\%; and The Istanbul Stock Exchange 100 index gained 56\% in value (Turkish Central Bank, 2015b). When compared with housing prices, an investor who bought a house in Istanbul in last five years will have has achieved $57 \%$ greater gross return than from the other investments.

This, however, is not the case for other City housing markets in Turkey. Investing capital in US Dollars instead of buying a house in city other than Istanbul would achieve an average of $33 \%$ greater gross return. The average return of investing gold and Istanbul Stock exchange would similar to the return from buying a house.

The general price level (inflation) in the period between 2010 and 2015 in Turkey has been $46 \%$ (assuming the year 2010 as 100 basis points, the year 2015 is 146 basis points) (Turkish Central Bank, 2015c). Thus, in the last 5 years period, investors who bought a house in Istanbul has achieved a $64 \%$ return on average in real terms. The average real increase in housing prices outside Istanbul is around $17 \%$.

\section{Credit availability}

The availability of credit and mortgage finance also appears to play an important part in what has happened in the housing part of the construction sector. The total amount of annual mortgage credits, the number of people accessing credit and mortgage credit interest rates for 2002 to 2014 are discussed below (The Banks Association of Turkey, 2015). Theoretically, we might expect to see an inverse relation expected between mortgage interest rates and the amount of mortgage credits; and, conversely, we would anticipate a positive relationship between between economic growth and mortgage credit levels.

Total mortgage credits were 258 million TL in 2002, rising to 36524 million TL by 2014. Importantly there was a change in mortgage legislation enacted in 2007 which introduced loans at more favourable lending rates and over longer terms than had previously been the case. The mortgage credit volume was stable between 2006 and 2008. For the three years before this period, however the year on year increase in total mortgage credits in was between $200 \%$, and $400 \%$. More recently we have seen a much more modest 77\% increase between 2012 and 2013, and a decrease of $28 \%$ in 2014 (The Banks Association of Turkey, 2015, see Figure 5).

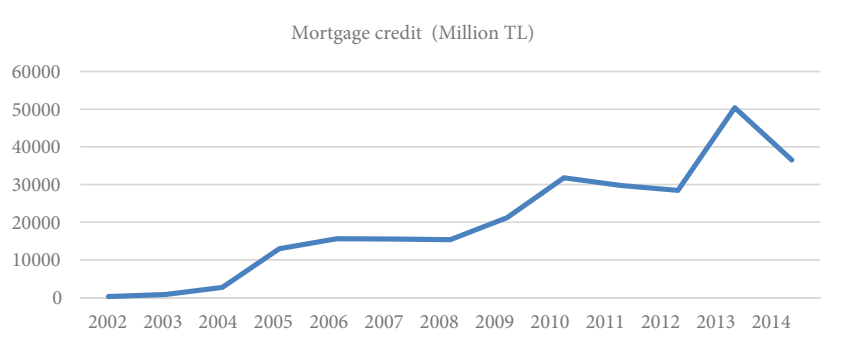

Figure 5. Mortgage credit availability

The total mortgage credit and the volume of credit users are closely related. While the 10915 people used mortgage credits in 2002, this amount reached to 384,000 in 2014 (Figure 6). The number of mortgage credit users increased $147 \%$ in 2003 relative to 2002 . The annual increase was $272 \%$ in 2004 and $171 \%$ in 2005 . The annual increase was $60 \%$ in 2013 before a year on year fall of $34 \%$ was observed in 2014 (The Banks Association of Turkey, 2015).

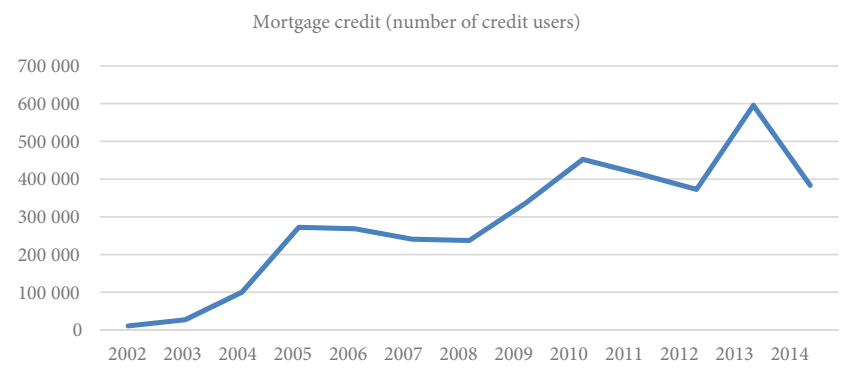

Figure 6. Mortgage credit users

Importantly, the scale of mortgage credit per capita has altered over the study period. The average credit amount used in 2002 is about $24,000 \mathrm{TL}$ rising to about 95,000 TL in 2014. The real per capita amount of credits increased $76 \%$ in 2005 according to previous year. Mortgage credit per capita decreased twice on a year on year basis in 2004 and 2009 by $9 \%$ and $2 \%$ respectively (The Banks Association of Turkey, 2015, see Figure 7). A continuous increase was observed in other years. The increase in house prices as well as lower down payment required to by borrowers 
Average mortgage credit per person (TL)

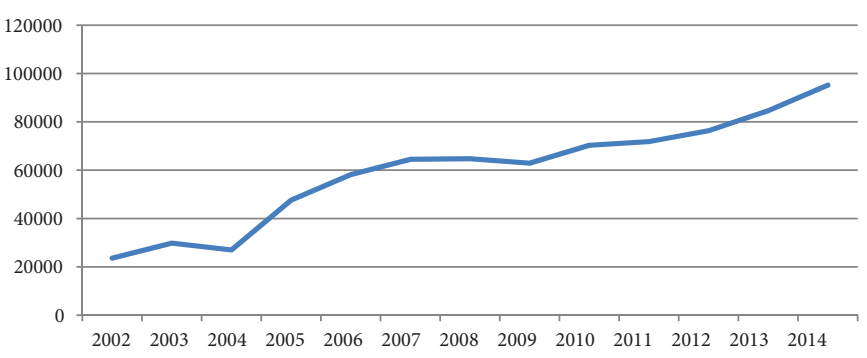

Figure 7. Mortgage credit per person

will have influenced the figures above. These trends are, of course, driven by lending in the three largest cities.

The demand for mortgage credits will also have been shaped by interest rate levels (see Figure 8, Turkish Central Bank, 2015b). Mortgage interest rates decreased from $54 \%$ to $10 \%$ between 2002 to 2014 . Within this 13 years period, there have been some fluctuations with the lowest annual rates reduction of $8 \%$ occurring in June 2013 .

The correlation between mortgage interest rates and credit expansion is strongly negative $(-0.87)$ between 2002-2014 periods. Within the same period, the correlation between the number of people using mortgage credit and mortgage credit interest rates is -0.9 ; and the correlation between the amount of mortgage credit and mortgage credit interest rates is -0.82 . Real GDP and mortgage credit expected to be associated.

The change in real GDP between 2002 and 2014 is shown in the graph below (Turkish Statistical Institute, 2015a, see Figure 9). The change in mortgage credit amount per person is reflected in Figure 7. These two graphs show the parallels between the expansion in mort-

Mortgage interest rate (\%)

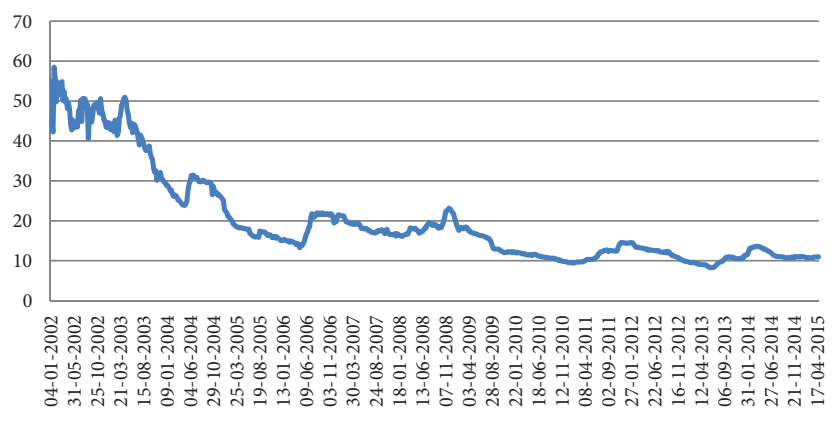

Figure 8. Mortgage interest rates

Real GDP (1998 base year, $1000 \mathrm{TL})$

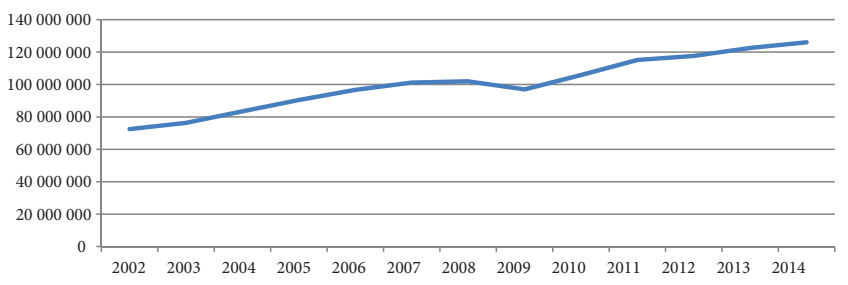

Figure 9. Real GDP trends gage credits per person, driving housing demand, and real GDP. The correlation coefficient between the two series is 0.97 with the only divergence occurring in 2003-2004.

There is a strong correlation between total mortgage credits, the number of mortgage credit users, the level of mortgage credits per person, mortgage interest rates and real GDP in Turkey between 2002 and 2014. Beyond the mortgage credit interest rates and real growth, the other factors that expected to affect the mortgage credits and housing sales are the change in house sales prices, the credit maturity period and household income. The importance of house prices and household income distribution, which vary spatially, are of course important sources or potential variation in market conditions within the country.

\subsection{Statistical analysis of economic fundamentals and construction activity}

\subsubsection{Preliminary regression analysis}

Four different regression equations were estimated in order to explore the relationship between construction growth and socio-economic indicators. Equation estimations were produced using the spatial analysis program, GeoDa. Single estimations show that there is a positive and linear relationship between construction growth and socio-economic change. However, the sizeable unexplained part of the equation suggests that there are other important factors not included in the equation. The regression results are reported in Table 1.

The Local Moran-I statistic was computed using the residuals from these regression estimations. The results of the four different Local Moran-I statistic are presented in Table 2 . The $\mathrm{Z}$ scores and $\mathrm{p}$ values show that the computed index values are statistically significant. The Moran-I values point to positive spatial autocorrelation and the null hypothesis of spatial randomness was rejected. Thus, we can ascertain that there was statistically significant moderate clustering in Turkey which affirms the notion that there is very uneven spatial growth in the construction sector. The provinces clustering distribution can be found in Table 3 and in Figure 10.

The distribution of localities to clusters reveals some remarkable differences between periods. From 2003 to 2013, new provinces have been added to the HH cluster. The geographical distribution of those clusters includes two distinct groups that appear in 2013. Interestingly, these clusters are quite dispersed geographically and the provinces differ in terms of their size and economic functions. The provinces included in the LL cluster are quite different in terms of geographic location by 2013. At this point, there are three interesting outliers in terms of housing construction activity, each of which is surrounded by provinces where housing construction is relatively low. These 3 outliers are important because they illustrate how polarized housing construction growth is across the country (Figure 10). 
Table 1. Summary of output: ordinary least square estimations

\begin{tabular}{|c|c|c|c|c|c|c|c|c|}
\hline & \multicolumn{2}{|c|}{$\begin{array}{l}\text { Total construction } \\
\text { permit }(2003)\end{array}$} & \multicolumn{2}{|c|}{$\begin{array}{l}\text { Housing construction } \\
\text { permit }(2003)\end{array}$} & \multicolumn{2}{|c|}{$\begin{array}{l}\text { Total construction } \\
\text { permit }(2013)\end{array}$} & \multicolumn{2}{|c|}{$\begin{array}{l}\text { Housing construction } \\
\text { permit }(2013)\end{array}$} \\
\hline & Constant & $\beta$ & Constant & $\beta$ & Constant & $\beta$ & Constant & $\beta$ \\
\hline Coefficient & 510.3877 & 600.028 & 439.9318 & 524.5776 & 1214.064 & 1497.561 & 1055.323 & 1345.642 \\
\hline Std. Error & 56.8257 & 57.1816 & 51.6656 & 51.9891 & 118.4819 & 119.2178 & 108.0866 & 108.758 \\
\hline t-statistic & 8.9816 & 10.4933 & 8.5149 & 10.0901 & 10.2468 & 12.5615 & 9.7636 & 12.3728 \\
\hline Prob(t-st.) & 0.0000 & 0.0000 & 0.0000 & 0.0000 & 0.0000 & 0.0000 & 0.0000 & 0.0000 \\
\hline R-squared & \multicolumn{2}{|c|}{0.58} & \multicolumn{2}{|c|}{0.56} & \multicolumn{2}{|c|}{0.66} & \multicolumn{2}{|c|}{0.65} \\
\hline Adj. $\mathrm{R}^{2}$ & \multicolumn{2}{|c|}{0.57} & \multicolumn{2}{|c|}{0.55} & \multicolumn{2}{|c|}{0.66} & \multicolumn{2}{|c|}{0.65} \\
\hline F-statistic & \multicolumn{2}{|c|}{110.111} & \multicolumn{2}{|c|}{101.811} & \multicolumn{2}{|c|}{157.793} & \multicolumn{2}{|c|}{153.086} \\
\hline $\operatorname{Prob}(\mathrm{F}-\mathrm{st})$ & \multicolumn{2}{|c|}{0.0000} & \multicolumn{2}{|c|}{0.0000} & \multicolumn{2}{|c|}{0.0000} & \multicolumn{2}{|c|}{0.0000} \\
\hline Log likelihood & \multicolumn{2}{|c|}{-619.136} & \multicolumn{2}{|c|}{-611.425} & \multicolumn{2}{|c|}{-678.652} & \multicolumn{2}{|c|}{-671.214} \\
\hline Akaike Info Criterion & \multicolumn{2}{|c|}{1242.27} & \multicolumn{2}{|c|}{1226.85} & \multicolumn{2}{|c|}{1361.3} & \multicolumn{2}{|c|}{1346.43} \\
\hline Schwarz Criterion & \multicolumn{2}{|c|}{1247.06} & \multicolumn{2}{|c|}{1231.64} & \multicolumn{2}{|c|}{1366.09} & \multicolumn{2}{|c|}{1351.22} \\
\hline
\end{tabular}

Table 2. Local Moran-I

\begin{tabular}{|l|c|c|c|c|c|c|}
\hline & z-value & Std. $d$ & Mean & I & E[I] & Pseudo-p \\
\hline Total construction permit (2003) & 5.0426 & 0.0694 & -0.0098 & 0.3402 & -0.0125 & 0.001 \\
\hline Housing construction permit (2003) & 5.1166 & 0.0672 & -0.0144 & 0.3296 & -0.0125 & 0.001 \\
\hline Total construction permit (2013) & 4.1146 & 0.0677 & -0.0126 & 0.2662 & -0.0125 & 0.001 \\
\hline Housing construction permit (2013) & 4.1127 & 0.0657 & -0.0129 & 0.2573 & -0.0125 & 0.001 \\
\hline
\end{tabular}

I: Moran statistic; E[I]: expected value of Moran I; Mean: the average of Moran-I for the simulated distribution.

Table 3. The provinces according to their clustering distribution

\begin{tabular}{|c|c|c|c|c|}
\hline & $\mathrm{HH}$ & LL & $\mathrm{HL}$ & $\mathrm{LH}$ \\
\hline Construction 2003 & $\begin{array}{l}\text { Balikesir } \\
\text { Manisa } \\
\text { Izmir } \\
\text { Aydin } \\
\text { Mugla }\end{array}$ & $\begin{array}{l}\text { Edirne } \\
\text { Kirklareli } \\
\text { Tekirdag } \\
\text { Istanbul } \\
\text { Kocaeli }\end{array}$ & & \\
\hline Construction 2013 & $\begin{array}{l}\text { Balikesir } \\
\text { Manisa } \\
\text { Izmir } \\
\text { Aydin } \\
\text { Agri } \\
\text { Van } \\
\text { Bitlis } \\
\text { Siirt } \\
\text { Sirnak } \\
\text { Batman } \\
\text { Mardin } \\
\text { Diyarbakir }\end{array}$ & $\begin{array}{l}\text { Edirne } \\
\text { Bartin } \\
\text { Karabuk } \\
\text { Zonguldak } \\
\text { Bolu } \\
\text { Duzce }\end{array}$ & Istanbul & \\
\hline $\begin{array}{l}\text { Housing construction } \\
2003\end{array}$ & $\begin{array}{l}\text { Balikesir } \\
\text { Manisa } \\
\text { Izmir } \\
\text { Aydin } \\
\text { Denizli } \\
\end{array}$ & $\begin{array}{l}\text { Edirne } \\
\text { Kirklareli } \\
\text { Tekirdag } \\
\text { Istanbul }\end{array}$ & & \\
\hline $\begin{array}{l}\text { Housing construction } \\
2013\end{array}$ & $\begin{array}{l}\text { Balikesir } \\
\text { Manisa } \\
\text { Izmir } \\
\text { Aydin } \\
\text { Agri } \\
\text { Van } \\
\text { Bitlis } \\
\text { Siirt } \\
\text { Sirnak } \\
\text { Batman } \\
\text { Diyarbakir } \\
\text { Hakkari }\end{array}$ & $\begin{array}{l}\text { Edirne } \\
\text { Bartin } \\
\text { Karabuk } \\
\text { Zonguldak } \\
\text { Bolu } \\
\text { Duzce }\end{array}$ & $\begin{array}{l}\text { Istanbul } \\
\text { Ankara } \\
\text { Afyon }\end{array}$ & \\
\hline
\end{tabular}




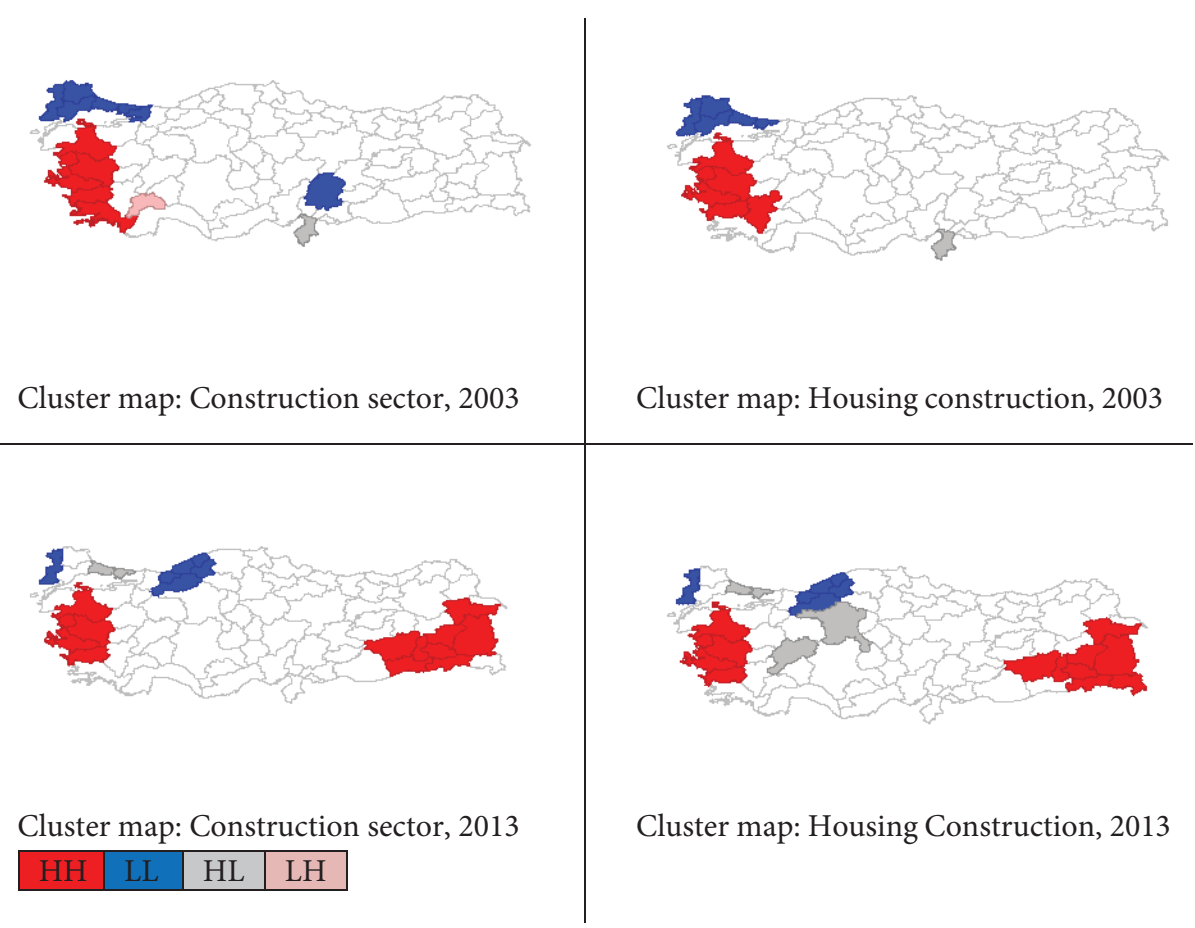

Figure 10. The map of clustering distribution

\subsection{Reflections on the statistical results and other related evidence}

When we compare both the relative performance (between regions) and the change in performance over time on a number of key indicators, it is possible to draw some tentative conclusions about the utility of the typology. This section of the paper looks at NUTS and other secondary data sources in an attempt to consider the extent to which the emergent patterns of development activity and the model results might resonate with the established stylized facts about what is happening in different provinces.

\subsubsection{Relationships to GVA}

The gross value added (GVA) data in NUTS2 level between 2004 and 2011 provides useful headline information on the economic wellbeing of different parts of the country. The data, which unfortunately are not available after 2011, shows that Istanbul is the most significant NUTS2 region in the country's economy, and its contribution is $27 \%$ of GVA. Ankara (8\%) and Izmir (6\%) are the next most important. Eastern and Southern Marmara provinces (Kocaeli, Sakarya, Bursa, Eskisehir) stand out at the forefront of regional added value rankings (Turkish Statistical Institute, 2015c). The lowest regional value-added provinces are Agri, Kars, Igdir and Ardahan. These are followed at the bottom end of the distribution by Kastomonu, Cankiri and Sinop regions and Erzurum, Erzincan and Bayburt regions (see Table 4).

Arguably the changes in the GVA shares of different region is a more important influence on construction activity than the headline figures above. Table below ranks
Table 4. Regions ranked by NUTS2 economic performance

\begin{tabular}{|l|l|}
\hline 1 & Mardin, Batman, Şırnak, Siirt \\
\hline 2 & Tekirdağ, Edirne, Kırklareli \\
\hline 3 & Kocaeli, Sakarya, Düzce, Bolu, Yalova \\
\hline 4 & Gaziantep, Adıyaman, Kilis \\
\hline 5 & Manisa, Afyonkarahisar, Kütahya, Uşak \\
\hline 6 & Hatay, Kahramanmaraş, Osmaniye \\
\hline 7 & Trabzon, Ordu, Giresun, Rize, Artvin, Gümüşhane \\
\hline 8 & Balıkesir, Çanakkale \\
\hline 9 & Bursa, Eskişehir, Bilecik \\
\hline 10 & Van, Muş, Bitlis, Hakkari \\
\hline 11 & Ankara \\
\hline 12 & Antalya, Isparta, Burdur \\
\hline 13 & Malatya, Elazı̆̆, Bingöl, Tunceli \\
\hline 14 & Adana, Mersin \\
\hline 15 & Şanlıurfa, Diyarbakır \\
\hline 16 & Kırıkkale, Aksaray, Niğde, Nevşehir, Kırşehir \\
\hline 17 & Istanbul \\
\hline 18 & Kayseri, Sivas, Yozgat \\
\hline 19 & Konya, Karaman \\
\hline 20 & Samsun, Tokat, Çorum, Amasya \\
\hline 21 & Izmir \\
\hline 22 & Ağrı, Kars, Iğdır, Ardahan \\
\hline 23 & Erzurum, Erzincan, Bayburt \\
\hline 24 & Aydın, Denizli, Muğla \\
\hline 25 & Zonguldak, Karabük, Bartın \\
\hline 26 & Kastamonu, Çankırı, Sinop \\
\hline & \\
\hline 19
\end{tabular}


the provinces that have the highest increase in their added value between 2004 and 2011. Between those years, the added value increased the most in the Mardin, Siirt, Batman and Sirnak region, which make a remarkable move from $22^{\text {nd }}$ to $1^{\text {st }}$ in the rank order. The Moran-I statistics put Siirt, Batman and Sirnak in the $\mathrm{HH}$ quadrant in 2013. The second most striking change is in the Tekirdag, Edirne, Kirklareli region. In this case, Moran-I statistics put the region in the LL quadrant in both 2003 and 2013. This chimes with expectations about the socio-economic basis for development in these areas. The other region of note is Kastamonu, Cankiri and Sinop. In that region, both the level of added value in the region (25th in the rank order) and the increase in added value between 2004 and 2011 (26th) is lowest.

If we use Value added per capita rather than GVA, the rank order position also change for Istanbul, Eastern Marmara, Ankara, Southern Marmara and Western Marmara regions by 2011. The Van, Mus, Bitlis and Hakkari region (Turkish Statistical Institute, 2015c) has the lowest rank on that measure. Again, this resonates with what the regression and Morans analysis might lead us to expect. The only unanticipated result is the inclusion of Siirt, Batman and Sirnak regions in the $\mathrm{HH}$ quadrant in 2013, when lower levels of development might reasonably have been expected.

\subsubsection{The relationship with mortgage finance}

As we note in section 3.1, the availability of finance can be important driver or significant constraint on sales and development activity. Turkish Statistical Institute data in 2011 shows the similarity between two ranks: the 10 provinces where the housing sales with mortgage credit are the highest and the NUTS2 regions where the highest value added is produced (Turkish Statistical Institute, 2015c; The Banks Association of Turkey, 2015). The Moran-I statistics show Istanbul and Ankara in the HL quadrant in 2013. Their appearance is likely to resonate with most analysts expectations, given that it implies a break between construction activity and underlying economic fundamentals.

Table 5. NUTS2 value added and mortgages sales

\begin{tabular}{|l|l|}
\multicolumn{1}{|c|}{$\begin{array}{c}\text { The highest value added } \\
\text { NUTS2 regions }-2011\end{array}$} & \multicolumn{1}{c|}{$\begin{array}{c}\text { The highest mortgage } \\
\text { sales }-2011\end{array}$} \\
\hline Istanbul & Istanbul \\
\hline Ankara & Ankara \\
\hline Izmir & Izmir \\
\hline Bursa, Eskisehir, Bilecik & Antalya \\
\hline $\begin{array}{l}\text { Kocaeli, Sakaraya, Duzce, Bolu, } \\
\text { Yalova }\end{array}$ & Bursa \\
\hline Antalya, Isparta, Burdur & Kocaeli \\
\hline Adana, Mersin & Mersin \\
\hline & Adana \\
\cline { 2 - 3 } & Kayseri \\
\cline { 2 - 3 } & Eskisehir \\
\hline
\end{tabular}

We encounter similar patterns when we examine total housing sales and total mortgage credits and deposits across the provinces. In 2014, the provinces with the six highest mortgage sales levels are Istanbul, Ankara, Izmir, Antalya, Bursa and Kocaeli, respectively. In 2011, the provinces with highest mortgage credit use were Istanbul, Ankara, Izmir, Antalya, Bursa, Kocaeli (see Table 5). Total housing sales, total credits and mortgage credits are correlated and all those values are the highest in provinces where the total value added is highest. The NUTS2 level value added or value added per person ranking is very consistent with total housing sales and total credits ranking.

Thus, when taken together, the statistical analysis and our exploration of secondary data show that there is uneven relationship between economic fundamentals, policy intervention and development activity. There are, however, interesting anomalies in certain places (for instance, Afyon in HL quadrant) at some points in time that merit further investigation to help us understand the extent to which policy might be distorting activity levels and leading to a break between construction activity and economic fundamentals.

\section{Conclusions}

In Turkey, as in many countries, there has been a strong narrative within government that has emphasized the importance of construction activity as a driver in economic growth. This has given shape to a central government policy narrative that has sought to ensure that planners and other urban policy makers develop plans and strategies that support real estate development activity. Against this backdrop, and a recent history of uneven spatial development, this paper seeks to begin to understand what this might mean for the drivers of construction activity broadly and housing construction in particular within different provinces. It seeks to develop an understanding of both the relationship between public policy, economic drivers and levels of development activity.

The evidence suggests that uneven spatial development might be explained in different ways in different parts of the country. In many parts of the country, there has been a reasonable degree of consistency between economic fundamentals and constructions activity. But there are exceptions in some regions at some points in time. There are some provinces where it seems likely that policy is creating conditions where development levels are outstripping market requirement which, of course, might seek to destabilise the real estate market and wider economy (Renaud, 1997). In others, it may be the case that development levels are below what might be required to meet market requirements and to support the growth agenda. We argue that these initial findings require further investigation. We propose that the clusters derived in this paper should be used to frame that analysis.

Specifically, we would argue that there are several ways that these clusters can be used in further study. First, the two geographically dispersed sub-clusters in the $\mathrm{HH}$ quadrant can be explored further using secondary data. The 
sub-clusters located at the west side and east side of the country were both expected to reflect the different characteristics of either their social and economic environments or their natural and cultural environments. Moreover, these 2 sub-clusters also differ in terms of their strategic importance in the country's political landscape. Given the differences in functional and political significance, these sub-clusters offer useful case study contexts within which to explore the role of large-scale public investments, government incentives, private sector investments backed by central planning and their impact on construction growth.

Second, given that LL quadrant changed its geographical composition, it offers a chance to explore different issues. The fact that numerous localities now exhibit different relationships between construction activity and economic fundamentals means that these study area offer insight into the change relationship between construction growth and market and policy influences. The new provinces included in the cluster are economically reliant coal mining and the iron-steel industry. Therefore, the cluster provides an opportunity to reflect how important the power of economic development and positive expectations of its sustainability on construction growth.

Third, the HL quadrant captures a number of polarized provinces in housing construction growth. The major factors stimulating the dense construction growth in these areas are not clearly related to economic drivers and, thus, the role and significance of central and local planning policies and practices should be investigated. These cases offer novel sights into the role of planning in creating economic capacity.

Finally, the most important consequence of uneven distribution is its potential of creating local bubbles. The provinces in the HL quadrant all exhibit local housing bubbles or, on the basis of the data, appear to be candidates for local bubbles in the near future. The risk of a bubble appears to increase where house prices have risen above the long term and national average levels. The influence of land values on construction costs is important at the point. Land supply is, of course, influence significantly by planning policy. In the circumstances, planning policy is unlikely to be operating independently of market forces which further suggests that the role of market actors in shaping planning policies and planning decisions needs to be examined in particular provinces.

Overall, this paper develops an approach to examining the relationship between state intervention, economic fundamentals and housing construction activity. The spatial and statistical analysis poses a set of further question that might usefully be explored using complementary qualitative analysis.

\section{Acknowledgement}

This paper based on the research project entitled 'Construction, Economic Development, and Planning Policies: Investigating the Causal Links' that funded by British Academy Newton Fund.

\section{References}

Adams, D., \& Tiesdell, S. (2010). Planners as market actors: rethinking state-market relations in land and property. Planning Theory \& Practice, 11(2), 187-207.

https://doi.org/10.1080/14649351003759631

Adams, D., \& Watkins, C. (2014). The value of planning. London: Royal Town Planning Institute.

Barras, R. (1984). The office development cycle in London. Land Development Studies, 1, 35-50. https://doi.org/10.1080/02640828408723866

Barras, R. (2009). Building cycles: growth and instability. Oxford: Wiley-Blackwell. https://doi.org/10.1002/9781444310009

Begg, I. (Ed.). (2002). Urban competitiveness: policies for dynamic cities. Bristol: The Policy Press.

Bon, R. (1992). The future of international construction. Habitat International, 16, 119-128.

https://doi.org/10.1016/0197-3975(92)90068-A

Bramley, G. (1998). Measuring planning: indicators of planning restraint and its impact on housebuilding and house price. Environment and Planning A, 25(7), 1021-1051.

https://doi.org/10.1068/a251021

Bramley, G. (2003). Planning regulation and housing supply in a market system. Housing Economics and Public Policy. United Kingdom: Blackwell.

Bramley, G. (2013). Housing market models and planning. Town Planning Review, 84(1), 9-35. https://doi.org/10.3828/tpr.2013.2

Bramley, G., \& Watkins, C. (1995). Circular projections: household growth, housing development and the household projections. Council for the Protection of Rural England, London.

Buckley, K. A. H. (1952). Urban building and real estate fluctuations in Canada. Canadian Journal of Economics and Political Science, 18(1), 41-62. https://doi.org/10.2307/138533

Celik, O. (2013). Changing forms and strategies of state intervention in the housing of the poor in Istanbul. Unpublished $\mathrm{PhD}$ Thesis, University of Sheffield.

Coskun, Y. (2011). The global financial crisis and the Turkish housing market. Housing Finance International, 25(3), 6-14.

Dawkins, C. J., \& Nelson, A. C. (2002). Urban containment policies and housing prices: an international comparison with implications for future research. Land Use Policy, 19, 1-12. https://doi.org/10.1016/S0264-8377(01)00038-2

DiPasquale, D., \& Wheaton, W. C. (1996). Urban economics and real estate markets. Englewood Cliffs, NJ: Prentice Hall.

Eraydin, A., \& Tasan-Kok, T. (2014). State response to contemporary urban movements in Turkey: a critical overview of state entrepreneurialism and authoritarian interventions. Antipode, 46(1), 110-129. https://doi.org/10.1111/anti.12042

Fainstein, S. S. (2001). The city builders: property development in New York and London, 1980-2000. University Press of Kansas.

Fisher, J. D. (1992). Integrating research on markets for space and capital. Real Estate Economics, 20, 161-180. https://doi.org/10.1111/1540-6229.00578

Grenadier, S. R. (1995). The persistence of real estate cycles. Journal of Real Estate Finance and Economics, 10, 95-119. https://doi.org/10.1007/BF01096984

Henneberry, J., McGough, T., \& Mouzakis, F. (2005a). Estimating the impact of planning on commercial property markets. In D. Adams, C. Watkins, M. White (Eds.), Planning, Public Policy and Property Markets (pp. 105-126). Oxford: Blackwell. https://doi.org/10.1002/9780470757789.ch6 
Henneberry, J., McGough, T., \& Mouzakis, F. (2005b). The impact of planning on local business rents. Urban Studies, 42, 471-502. https://doi.org/10.1080/00420980500035261

Henneberry, J., McGough, T., Rowley, S., \& Smith, R. (2003). The economic consequences of planning for business: planning and business rents. Final Report to ODPM, Department of Town and Regional Planning, University of Sheffield, Sheffield.

Jackson, C. (2006). Retail planning policy change and institutional investment. Regional Studies, 40, 555-561. https://doi.org/10.1080/00343400600757734

Jackson, C., \& Watkins, C. (2005). Planning policy and retail property markets: measuring the dimensions of planning intervention. Urban Studies, 42, 1453-1469. https://doi.org/10.1080/00420980500150896

Jackson, C., \& Watkins, C. (2011). Planning policy and retail property investment. Urban Studies, 48(11), 2321-2338. https://doi.org/10.1177/0042098010385157

Jackson, C., \& Watkins, C. (2007). Supply-side policies and retail property market performance. Environment and Planning A, 39(5), 1134-1146. https://doi.org/10.1068/a38250

Keogh, G. (1994). Use and investment markets in British real estate. Journal of Property Valuation and Investment, 12(4), 58-72. https://doi.org/10.1108/14635789410069980

Key, T., Zarkesh, F., MacGregor, B. D., \& Nanthakumaran, N. (1994). Understanding the property cycle: economic cycles and property cycles. London: Royal Institution of Chartered Surveyors.

Nanthakumaran, N., Watkins, C., \& Orr, A. (2000). Understanding property market dynamics: insights from modelling the supply-side adjustment mechanism. Environment and Planning A, 32(4), 655-672. https://doi.org/10.1068/a31176

Renaud, B. (1997). The 1985 to 1994 global real estate cycle: an overview. Journal of Real Estate Literature, 5(1), 13-44. https://doi.org/10.1023/A:1008623304689

Ruddock, L., \& Lopes, J. (2006). The construction sector and economic development: the Bon curve. Construction Management and Economics, 24(7), 717-723. https://doi.org/10.1080/01446190500435218

Strassmann, P. (1970). The construction sector in economic development. Scottish Journal of Political Economy, 17(3), 390410. https://doi.org/10.1111/j.1467-9485.1970.tb00715.x

Sun, Y., Mitra, P., \& Simone, A. (2013). The driving forces behind boom and boost in Europe. IMF Working Paper (WP/13/181), International Monetary Fund.
The Banks Association of Turkey. (2015). Consumer loans and housing loans quarterly. Retrieved from https://www.tbb.org. tr/en/banks-and-banking-sector-information/data-querysystem $/ 21$

Tsolacos, S., McGough, T., \& Keogh, G. (1998). Modelling use, investment and development in the British office market. Environment and Planning A, 30(8), 1409-1427.

https://doi.org/10.1068/a301409

Turin, D. A. (1969). The construction industry: its economic significance and its role in development. London: University College, Environmental Research Group.

Turk, S. S., \& Korthals Altes, W. K. (2010). Institutional capacities in the land development for housing on greenfield sites in Istanbul. Habitat International, 34(2), 183-195. https://doi.org/10.1016/j.habitatint.2009.09.002

Turkish Central Bank. (2015a). Hedonic housing price indexes, July 2015. Retrieved from https://evds2.tcmb.gov.tr/index. php?/evds/dashboard/310

Turkish Central Bank. (2015b). Electronic data center, July 2015. Retrieved from https://evds2.tcmb.gov.tr/

Turkish Central Bank. (2015c). Monetary policy and inflation developments, July 2015. Retrieved from http://www.tcmb.gov. tr/wps/wcm/connect/TCMB+EN/TCMB+EN/Main+Menu/ STATISTICS/Chart+Gallery/

Turkish Statistical Institute. (2015a). Gross Domestic Product at current prices by kind of economic activity, July 2015. Retrieved from http://www.turkstat.gov.tr/PreTablo.do?alt_id=1108

Turkish Statistical Institute. (2015b). Construction labor input indices, July 2015. Retrieved from http://www.turkstat.gov.tr/ PreTablo.do?alt_id $=1023$

Turkish Statistical Institute. (2015c). Regional Gross Values Added at current prices, July 2015. Retrieved from https://biruni.tuik. gov.tr $/$ medas $/$ : $\mathrm{kn}=116 \&$ locale $=$ en

Turkun, A. (2011). Urban regeneration and hegemonic power relationships. International Planning Studies, 16(1), 61-72. https://doi.org/10.1080/13563475.2011.552473

White, M., \& Allmendinger, P. (2003). Land-use planning and housing market: a comparative review of the UK and the USA. Urban Studies, 40, 953-972. https://doi.org/10.1080/0042098032000074263

Wong, C., \& Watkins, C. (2009). Conceptualising spatial planning outcomes: towards and integrative measurement framework. Town Planning Review, 80(4-5), 481-516. https://doi.org/10.3828/tpr.2009.8 